\title{
Evaluation of oxidative stress in Vigna radiata $L$. in response to chlorpyrifos
}

\author{
T. Parween $\cdot$ S. Jan $\cdot$ Mahmooduzzafar $\cdot$ T. Fatma
}

Received: 7 April 2011/Revised: 2 August 2011/Accepted: 18 November 2011/Published online: 24 July 2012

(c) CEERS, IAU 2012

\begin{abstract}
This study aims to evaluate the effect of chlorpyrifos on several metabolic and stress related parameters of Vigna radiata L. Twenty-day-old plants were exposed to several concentrations of chlorpyrifos, ranging from 0 to $1.5 \mathrm{mM}$ through foliar spray in the field condition. Analyses were done at pre-flowering (Day 5), flowering (Day 10), and post-flowering (Day 20) stages after the treatment. Lipid peroxidation rate, proline, dehydroascorbate, oxidized and total glutathione were all ascended. Chlorpyrifos enhanced lipid peroxidation rate and proline content with $1.5 \mathrm{mM}$ at Day 20 whereas dehydroascorbate, oxidized and total glutathione were increased in $1.5 \mathrm{mM}$ at Day 10 . However, dose dependence significantly declined in content of ascorbate and reduced glutathione levels were observed at all growth stages. Among the enzymatic antioxidants, activities of superoxide dismutase, ascorbate peroxidase and glutathione reductase enhanced significantly in all the concentrations at Day 10. Maximum catalase activity was observed at Day 10 in control and it declined thereafter. The above results clearly depicted the provoked state of oxidative stress under chlorpyrifos exposure in Vigna radiata L. and therefore can be used to evaluate the degree of insecticide contamination to plant, which may be serving as biomarker in Vigna radiata $\mathrm{L}$.
\end{abstract}

Keywords Ascorbate-glutathione cycle - Insecticide . Mung bean $\cdot$ Oxidative stress

T. Parween · T. Fatma ( $₫)$

Department of Biosciences, Jamia Millia Islamia

(Central University), New Delhi 110025, India

e-mail: fatma_cbl@yahoo.com

S. Jan · Mahmooduzzafar

Department of Botany, Jamia Hamdard,

New Delhi 110062, India

\section{Introduction}

The use of synthetic pesticides as crop protection chemicals has become the most accepted ecological weapon for assured crop production. With the restricted use of most of the organochlorine insecticides, the organophosphorus compounds are taking the major share of insecticide consumption in India (Aditya et al. 1997). Chlorpyrifos [O,Odiethyl $O$-(3,5,6-trichloro-2-pyridyl) phosphorothioate] is a broad-spectrum organophosphate insecticide being used for more than a decade to control foliar insects that affect agricultural crops, to reduce pod damage (Khan et al. 2009; Kumar et al. 2010; Wu and Laird 2003; Rusyniak and Nanagas 2004), and subterranean termites (Venkateswara Rao et al. 2005). Chlorpyrifos produces hazardous effects on the environment when it is applied directly on plants or mixed with soil (Howard 1991). The absorption and translocation of chlorpyrifos residue by wheat and oil seed rape root has been studied by Wang et al. (2007) and it concluded that, the uptake rate of chlorpyrifos residue by these two plants increased with an increase in the amount of chlorpyrifos residue in soil. Parween et al. (2011) revealed that the exposure of an organophosphorous insecticide chlorpyrifos proved depressing for nitrogen metabolism and plant growth in Vigna radiata L. Previous studies have demonstrated that dimethoate causes a reduction in plant growth, photosynthetic pigments and photosynthetic activity of Glycine max L. (Panduranga et al. 2005) and Vigna unguiculata L. (Mishra et al. 2008). Continuous exposure to imadacloprid at higher doses significantly impaired the germination and growth of rice seeds and seedlings (Stevens et al. 2008) whereas adverse effects of mancozeb on morphological and anatomical traits of Lens culinaris L. at different developmental stages has been investigated by Bashir et al. (2007a, b). The 
blocked growth might have resulted from the inhibition of normal cell division or elongation. Besides, insecticides triggered oxidative stress by producing reactive oxygen species (ROS), e.g., superoxide anion radical $\left(\mathrm{O}_{2}^{-}\right)$and $\mathrm{H}_{2} \mathrm{O}_{2}$ (Mishra et al. 2008). Insecticide-induced oxidative stress was shown to alter the cellular redox balance by altering ascorbate-glutathione (Asc-Glu) cycle or damaging other antioxidant defense systems (Bashir et al. 2007b).

Plants have multiple strategies to confer their tolerance to insecticide- induced toxicity, and prevention of oxidative damage to cells has been suggested as one of the mechanisms of stress tolerance (Saraf and Sood 2002; Prasad et al. 2005). The antioxidant machinery is composed of enzymes and non-enzymatic components. The enzymatic components include ROS scavengers like superoxide dismutase (SOD), peroxidase (POD) and catalase (CAT) (Khan and Kour 2007). Such enzymatic based anti-oxidative system has been one of the important strategies for plants to respond to environmental stresses. In most cases, toxic organic compounds can give rise to the increased activities of antioxidant enzymes such as SOD, POD or ascorbate peroxidase (APX), which reflect not only the degree of toxicity but the ability to tolerate the stress as well (Wu and Von Tiedemann 2002; Peixoto et al. 2006; Song et al. 2007). Additionally, nonenzymatic (e.g., glutathione, tocopherols, ascorbate, and carotenoids) defense systems protect cells from injury also, by scavenging ROS (Pinto et al. 2003; Jan et al. 2012a).

Although a number of studies have demonstrated the effect of insecticides on various plants, but surprisingly, no attempt seems to have been made, to find out the effect of widely used insecticide chlorpyrifos on different developmental stages of vegetable crops, a situation, which is likely to exist in the agricultural fields. To the best of our knowledge, there is no information available so far about the effect of chlorpyrifos on antioxidant system of higher plants. In this context, present study will explain and elucidate the effects of chlorpyrifos-induced oxidative stress in plant cells, which may affect various enzymatic and nonenzymatic antioxidants involved in the Asc-Glu cycle in Vigna radiata $\mathrm{L}$. This research has been carried out in the Department of Botany, Jamia Hamdard (New Delhi; India) in April 2008-2009.

\section{Materials and methods}

\section{Chemicals}

All the chemicals used were of AR (analytical reagent) or GR (guaranteed reagent) quality. Most of the chemicals were the products of SRL, E. Merck, Aldrich-Sigma, S.D. fines. Chlorpyrifos (20\% EC) was supplied by Bharat Insecticides Limited, New Delhi (India).
Experimental setup and treatment

The seeds of Vigna radiata (L.) R. Wilcz were procured from Division of Genetics, Pulse Research Centre, Indian Agricultural Research Institute (IARI), New Delhi. The individual plot size was $6 \mathrm{~m}^{2}(4 \mathrm{~m} \times 1.5 \mathrm{~m})$ having 4 rows with a row to row distance of 15 inch and plant to plant distance of 10 inch. The number of plants per $\mathrm{m}^{2}$ was 15 . The field was ploughed and leveled prior to sowing. The plots were made with proper bunds along with necessary irrigation channels. Irrigation was done as and when required. The crop was kept free from weeds by regular manual weeding operations. Twenty-day-old seedlings were subjected to foliar application of three grades of chlorpyrifos (20\% E.C.) viz., 0 (control), $0.3,0.6$ and $1.5 \mathrm{mM} / 100 \mathrm{~mL}$ prepared by dissolving the required amount of chlorpyrifos in double distilled water. Each experiment was repeated three times with five replicates. Seedlings were collected on Day 5 (preflowering), 10 (flowering) and 20 (post-flowering) after the treatment to analyze the effects of chlorpyrifos treatment on lipid peroxidation rate, proline content, activities of enzymatic antioxidants like superoxide dismutase (SOD; 1.15.1.1), ascorbate peroxidase (APX; 1.11.1.11), catalase (CAT; 1.11.1.6) and glutathione reductase (GR; 1.6.4.2) and activities of non-enzymatic antioxidants like ascorbate (Asc) and glutathione (Glu) content.

Lipid peroxidation rate and proline analyses

Oxidative damage to leaf lipids was estimated by the content of a total of two thiobarbituric acid reactive substances (TBARS), expressed as equivalents of malondialdehyde (MDA). TBARS content in the leaves of $V$. radiata L. was determined by the method described by Cakmak and Horst (1991). Proline content in leaf samples was estimated by the method of Bates et al. (1973).

Extraction and determination of enzymatic activities

\section{SOD activity}

Fresh leaf material $(0.2 \mathrm{~g})$ was homogenized in $2.0 \mathrm{~mL}$ of extraction mixture containing $0.5 \mathrm{M}$ Na-phosphate buffer, pH 7.3, 3 mM EDTA, $1 \%$ PVP, $1 \%$ Triton X-100 and centrifuged at $10,000 \mathrm{rpm}$ at $4{ }^{\circ} \mathrm{C}$. The method of Dhindsa et al. (1981) was followed with slight modification for estimating SOD activity.

\section{APX activity}

Fresh leaf material $(1 \mathrm{~g})$, ground in $5 \mathrm{~mL}$ of extraction buffer (0.1 M K-phosphate, $\mathrm{pH} 7.0,3 \mathrm{mM}$ EDTA, $1 \%$ PVP, $1 \%$ Triton $\mathrm{X} 100$, and $1 \mathrm{mM}$ ascorbic acid), was 
centrifuged at $10,000 \mathrm{rpm}$ for $10 \mathrm{~min}$ at $4{ }^{\circ} \mathrm{C}$. APX activity was estimated by the method of Nakano and Asada (1981).

\section{CAT activity}

Fresh leaf material $(0.5 \mathrm{~g})$, ground in $5 \mathrm{~mL}$ of extraction buffer (0.5 M Na-phosphate, pH 7.3, 3 mM EDTA, $1 \%$ PVP, $1 \%$ Triton X 100) was centrifuged at 10,000 rpm for $20 \mathrm{~min}$. at $4{ }^{\circ} \mathrm{C}$. CAT activity was determined by the method of Aebi (1984).

\section{GR activity}

Fresh leaf material $(0.5 \mathrm{~g})$, ground in $2 \mathrm{~mL}$ of extraction buffer (0.1 M Na-phosphate, pH 7.0, 3 mM EDTA, $1 \%$ PVP, $1 \%$ Triton X 100) was centrifuged at 10,000 rpm for 10 min. GR activity was determined by the method of Foyer and Halliwell (1976) modified by Rao (1992).

Extraction and determination of enzymatic antioxidants

\section{Ascorbate content}

Fresh leaf tissue $(0.05 \mathrm{~g})$ was ground in $2 \mathrm{~mL}$ of $0.1 \mathrm{M} \mathrm{Na}-$ phosphate buffer ( $\mathrm{pH} 7$ ) and $1 \mathrm{mM}$ EDTA and centrifuged at $10,000 \mathrm{rpm}$ for $10 \mathrm{~min}$ ascorbate (Asc), dehydroascorbate (DHA) and total ascorbate (Asc + DHA) were estimated by a modified method of Law et al. (1983).

\section{Glutathione content}

Fresh leaf $(0.05 \mathrm{~g})$ was homogenized in $2 \mathrm{~mL}$ of $5 \%$ sulphosalicylic acid at $4{ }^{\circ} \mathrm{C}$. The homogenate was centrifuged at $10,000 \mathrm{rpm}$ for $10 \mathrm{~min}$. Reduced (GSH), oxidised (GSSG) and total glutathione (GSH + GSSG) were determined by the glutathione recycling method of Anderson (1985).

\section{Data analysis}

For all the enzymatic calculations, protein was determined by Bradford method (1976), using bovine serum albumin (BSA, Sigma, USA) as the standard. The data are expressed as mean $\pm \mathrm{SE}(n=5)$. The data were analyzed employing analysis of one-way variance (ANOVA) followed by a Duncan's multiple range test (DMRT) to determine whether the values were significantly different from the control. Least significance difference (LSD) at $5 \%$ probability level was used to detect the differences between treatment means.

\section{Results and discussion}

Among pesticides, organophosphates are most commonly used insecticides in the world. Over-generation of ROS is a rapid and sensitive response of plants to environmental stimuli (Jiang and Yang 2009; Jan et al. 2012b). Amongst ROS, $\mathrm{O}_{2}^{--}$and $\mathrm{H}_{2} \mathrm{O}_{2}$ were used to illustrate the degree of oxidative injury to cells. Peroxidation of membrane lipids is usually expressed by TBARS content accumulation. Lipid peroxidation may be the first step of cellular membrane damage by organophosphates (Hazarika et al. 2003). Table 1 showed age and dose dependent increase in lipid peroxidation rate in chlorpyrifos-exposed seedlings than that of the untreated seedlings. Compared to control, the average values of TBARS increased by $12.57 \%$ at Day 20 under $1.5 \mathrm{mM}$ chlorpyrifos concentration. Exposure of Glycine max. L. to insecticide deltamethrin or other pesticides led to increase in lipid peroxidation in leaves and root (Bashir et al. 2007b; Song et al. 2007). The increased lipid peroxidation in the present study suggested that ROSinduced damage may be one of the main toxic effects of chlorpyrifos.

It has been well known, that small metabolites like proline accumulate to a high level in plants when they are under stresses such as drought, salinity and other environmental stresses (Ashraf and Foolad 2007; Kovacik et al. 2009). Detoxification of ROS, protection of membrane integrity, stabilization of enzyme or proteins and tolerance to stresses have been the contributions by proline (Mittler 2002). Compared to the control, accumulation of proline content by $37.07 \%$ at Day 20 (Table 2) was observed. Enhanced proline content has been reported under insecticide stress (Bashir et al. 2007b) in Glycine max L. and herbicide stress (Wu et al. 2010) in rice, suggesting that it might prevent chlorpyrifos-induced production of ROS and protect plants from the oxidative damage. Thus, proline accumulation can be accepted as an indicator of chlorpyrifos-induced stress in Vigna radiata $\mathrm{L}$.

To mitigate and repair the damage caused by these ROS, plants have evolved complex antioxidant systems. The chlorpyrifos treated seedlings in this study have showed a significant enhancement in SOD activity, especially during the flowering stage (Day 10 after the treatment). The relatively low activity during post-flowering stage (Day 20 after the treatment) is mainly based on the fact that ageing leaf contains lower antioxidants than younger leaf (Haddad et al. 2009) as ageing is a period of catabolism of macromolecules which may cause the accumulation of ROS. Among the enzymatic antioxidant, SOD is an essential component of a plant's anti-oxidative defense system. An important role is played by SOD in dismutation of free radicals by the formation of $\mathrm{H}_{2} \mathrm{O}_{2}$. Overproduction of $\mathrm{H}_{2} \mathrm{O}_{2}$ 
Table 1 Variation in lipid peroxidation rate [(TBARS content) nmol/g fw] at various growth stages of Vigna radiata L. treated with different concentrations of chlorpyrifos

\begin{tabular}{llll}
\hline Treatments $(\mathrm{mM})$ & Day 5 & Day 10 & Day 20 \\
\hline 0 & $1.71 \pm 0.06^{\mathrm{d}}$ & $1.85 \pm 0.06^{\mathrm{d}}$ & $3.41 \pm 0.06^{\mathrm{d}}$ \\
0.3 & $1.79 \pm 0.20^{\mathrm{c}}(4.67)$ & $2.19 \pm 0.06^{\mathrm{c}}(19.02)$ & $3.62 \pm 0.12^{\mathrm{c}}(5.84)$ \\
0.6 & $1.94 \pm 0.11^{\mathrm{b}}(14.03)$ & $2.67 \pm 0.11^{\mathrm{b}}(45.10)$ & $3.81 \pm 0.08^{\mathrm{b}}(11.40)$ \\
1.5 & $2.01 \pm 0.07^{\mathrm{a}}(17.54)$ & $3.13 \pm 0.05^{\mathrm{a}}(69.56)$ & $3.85 \pm 0.31^{\mathrm{a}}(12.57)$ \\
LSD at $5 \%$ & NS & 0.25 & NS \\
\hline
\end{tabular}

Values in parentheses indicate percentage of variation with reference to respective controls. Mean \pm SE $(n=5)$. Values with different superscripts are significantly $(P<0.05)$ different from each other (Duncan's multiple range test)

Table 2 Variation in proline content ( $\mu \mathrm{g} / \mathrm{g}$ fw) at various growth stages of Vigna radiata L. treated with different concentrations of chlorpyrifos

\begin{tabular}{llll}
\hline Treatments $(\mathrm{mM})$ & Day 5 & Day 10 & Day 20 \\
\hline 0 & $14.24 \pm 0.30^{\mathrm{c}}$ & $32.12 \pm 0.30^{\mathrm{c}}$ & $98.47 \pm 0.14^{\mathrm{c}}$ \\
0.3 & $21.91 \pm 0.40^{\mathrm{b}}(53.86)$ & $52.05 \pm 0.32^{\mathrm{b}}(62.0)$ & $108.40 \pm 0.22^{\mathrm{b}}(10.08)$ \\
0.6 & $44.85 \pm 0.25^{\mathrm{b}}(214.95)$ & $76.43 \pm 0.29^{\mathrm{b}}(137.95)$ & $128.09 \pm 0.43^{\mathrm{b}}(30.07)$ \\
1.5 & $67.53 \pm 0.17^{\mathrm{a}}(374.22)$ & $88.46 \pm 0.19^{\mathrm{a}}(175.35)$ & $134.99 \pm 0.17^{\mathrm{a}}(37.07)$ \\
LSD at $5 \%$ & 0.96 & 0.77 & 0.94 \\
\hline
\end{tabular}

Values in parentheses indicate percentage of variation with reference to respective controls. Mean \pm SE $(n=5)$. Values with different superscripts are significantly $(P<0.05)$ different from each other (Duncan's multiple range test)

to eliminate the toxicity of $\mathrm{O}^{--}$is caused by SOD. Stimulation in activities of SOD was witnessed in Vigna leaves exposed to chlorpyrifos at different levels. A concentration dependent change was observed, with the highest activity at $1.5 \mathrm{mM}$ in Day 10 with $84.55 \%$ increase over the control (Table 3). Enhanced SOD activity was reported under insecticide (Bashir et al. 2007b) in Glycine max L., herbicide (Jianga et al. 2010; Wu et al. 2010) in wheat and rice, respectively, suggesting that SOD was stimulated by scavenging $\mathrm{O}_{2}^{--}$to protect Vigna plants from chlorpyrifos toxicity and the SOD activity was sufficient to cope with an increased concentration of chlorpyrifos.

Of the diverse anti-oxidative enzymes involved in the elimination of ROS, POD is another indicator of oxidative damage to plants. The breakdown of $\mathrm{H}_{2} \mathrm{O}_{2}$ and lignin biosynthesis in the presence of $\mathrm{H}_{2} \mathrm{O}_{2}$ is participated by POD (Bowler et al. 1992). APX is one type of POD but uses ascorbate as electron donor in the first step in the AscGlu cycle to remove $\mathrm{H}_{2} \mathrm{O}_{2}$ (Aebi 1984). In plant chloroplasts, to avoid oxidative stress, SOD and APX activities must not only be sufficiently high, but also balanced, so that $\mathrm{H}_{2} \mathrm{O}_{2}$ generated by the action of SOD upon superoxide radicals is eliminated by APX (Asada 2006). A pattern of activities similar to SOD was displayed by APX in this study (Table 4). Compared to the control, a dose dependent increase by $74.21 \%$ in Day 10 under $1.5 \mathrm{mM}$ treatment was observed. APX protects the cell against oxidative damage by detoxifying the toxic $\mathrm{H}_{2} \mathrm{O}_{2}$. The role of APX in the detoxification of $\mathrm{H}_{2} \mathrm{O}_{2}$ (Morimura et al. 1996) under insecticide-induced oxidative stress is suggested by its marked increase in the activity. Same results were observed under the fungicide (Jaleel et al. 2006; Gopi et al. 2007) and herbicide (Jianga et al. 2010) treatments.

CAT is one of the key enzymes involved in the removal of toxic $\mathrm{H}_{2} \mathrm{O}_{2}$. CAT activity also showed a similar variation trend as did SOD and APX with respect to age of the plant, thus having its maxima in Day 10 and declined thereafter over the respective control. On the contrary, the significant dose dependent decreased in CAT activity with all chlorpyrifos treatments up to $57.29,60.89$ and $71.32 \%$ at Day 5, 10 and 20, respectively (Table 5). Depressed CAT activity was reported under insecticide stress (Bashir et al. 2007b) in Glycine max L. and herbicide (Jianga et al. 2010) stress in wheat root, cobalt (Jaleel et al. 2009) in Vigna radiata $\mathrm{L}$. and temperature stress (Nagesh and Devaraj 2008) in Phaseolus vulgaris L. In the experiment of Rastgool and Alemzadeh (2011), decreased CAT activity under $\mathrm{Pb}$ treatment reported that resulted in increased lipid peroxidation may be because of decrease in $\mathrm{H}_{2} \mathrm{O}_{2}$ detoxification (Halliwell and Gutteridge 1985). Some of the reasons for decrease in CAT activity under stress conditions are changes in the assembling of CAT subunits and enzyme inactivation or proteolytic degradation by peroxisomal protease (MacRae and Ferguson 1985; Cakmak 2000), changes in enzyme structure due to binding non-essential metals to them (Florence and Stauber 1986). In the experiment of Mafakheri et al. (2011), significant decreased activity was measured in chickpea exposed to 
Table 3 Variation in superoxide dismutase (SOD) activity $\left(\mathrm{EU} \mathrm{mg} \mathrm{m}^{-1}\right.$ protein $\mathrm{h}^{-1}$ ) at various growth stages of Vigna radiata L. treated with different concentrations of chlorpyrifos

\begin{tabular}{llll}
\hline Treatments $(\mathrm{mM})$ & Day 5 & Day 10 & Day 20 \\
\hline 0 & $29.73 \pm 0.38^{\mathrm{d}}$ & $35.93 \pm 0.33^{\mathrm{d}}$ & $26.90 \pm 0.33^{\mathrm{d}}$ \\
0.3 & $39.89 \pm 0.38^{\mathrm{c}}(34.12)$ & $44.41 \pm 0.41^{\mathrm{c}}(23.56)$ & $35.88 \pm 0.34^{\mathrm{c}}(33.34)$ \\
0.6 & $46.01 \pm 0.39^{\mathrm{b}}(54.70)$ & $58.98 \pm 0.36^{\mathrm{b}}(64.10)$ & $41.90 \pm 0.29^{\mathrm{b}}(55.76)$ \\
1.5 & $58.89 \pm 0.48^{\mathrm{a}}(98.01)$ & $66.33 \pm 0.34^{\mathrm{a}}(84.55)$ & $52.01 \pm 0.34^{\mathrm{a}}(93.34)$ \\
LSD at $5 \%$ & 1.45 & 1.26 & 0.58 \\
\hline
\end{tabular}

Values in parentheses indicate percentage of variation with reference to respective controls. Mean \pm SE $(n=5)$. Values with different superscripts are significantly $(P<0.05)$ different from each other (Duncan's multiple range test)

Table 4 Variation in ascorbate peroxidase (APX) activity $\left(\mu \mathrm{mol} \mathrm{mg} \mathrm{m}^{-1}\right.$ protein $\left.\mathrm{min}^{-1}\right)$ at various stages of Vigna radiata L. treated with different concentrations of chlorpyrifos

\begin{tabular}{llll}
\hline Treatments $(\mathrm{mM})$ & Day 5 & Day 10 & Day 20 \\
\hline 0 & $1.57 \pm 0.01^{\mathrm{d}}$ & $1.59 \pm 0.04^{\mathrm{d}}$ & $1.26 \pm 0.04^{\mathrm{d}}$ \\
0.3 & $1.73 \pm 0.04^{\mathrm{c}}(10.89)$ & $2.41 \pm 0.04^{\mathrm{c}}(51.57)$ & $1.57 \pm 0.02^{\mathrm{c}}(24.8)$ \\
0.6 & $1.93 \pm 0.02^{\mathrm{b}}(23.07)$ & $2.57 \pm 0.03^{\mathrm{b}}(61.00)$ & $1.71 \pm 0.03^{\mathrm{b}}(36.8)$ \\
1.5 & $2.42 \pm 0.02^{\mathrm{a}}(55.12)$ & $2.78 \pm 0.01^{\mathrm{a}}(74.21)$ & $2.21 \pm 0.03^{\mathrm{a}}(76.00)$ \\
LSD at $5 \%$ & 0.08 & 0.11 & 0.13 \\
\hline
\end{tabular}

Values in parentheses indicate percentage of variation with reference to respective controls. Mean \pm SE $(n=5)$. Values with different superscripts are significantly $(P<0.05)$ different from each other (Duncan's multiple range test)

Table 5 Variation in catalase (CAT) activity $\left(\mathrm{mmol} \mathrm{mg}^{-1}\right.$ protein $\left.\mathrm{min}^{-1}\right)$ at various growth stages of Vigna radiata L. treated with different concentrations of chlorpyrifos

\begin{tabular}{llll}
\hline Treatments $(\mathrm{mM})$ & Day 5 & Day 10 & Day 20 \\
\hline 0 & $132.64 \pm 0.45^{\mathrm{a}}$ & $134.42 \pm 0.36^{\mathrm{a}}$ & $128.38 \pm 0.40^{\mathrm{a}}$ \\
0.3 & $98.14 \pm 0.48^{\mathrm{b}}(26.01)$ & $102.32 \pm 0.45^{\mathrm{b}}(23.88)$ & $96.50 \pm 0.36^{\mathrm{b}}(24.84)$ \\
0.6 & $89.35 \pm 0.46^{\mathrm{c}}(32.63)$ & $84.51 \pm 0.46^{\mathrm{c}}(37.12)$ & $79.93 \pm 0.36^{\mathrm{c}}(37.73)$ \\
1.5 & $56.66 \pm 0.3^{\mathrm{d}}(57.28)$ & $52.57 \pm 0.44^{\mathrm{d}}(60.89)$ & $36.82 \pm 0.43^{\mathrm{d}}(71.32)$ \\
LSD at $5 \%$ & 1.55 & 1.44 & 1.47 \\
\hline
\end{tabular}

Values in parentheses indicate percentage of variation with reference to respective controls. Mean \pm SE $(n=5)$. Values with different superscripts are significantly $(P<0.05)$ different from each other (Duncan's multiple range test)

drought stress at the vegetative stage where as the plant stressed during anthesis or both the vegetative stage and anthesis showed significantly higher CAT activity upon exposure to drought stress when compared to control.

GR is localized mainly in the chloroplast in which it represents about $80 \%$ of total GR activities in leaf tissues. It also can be found in cytosol, glyoxysomes, and peroxisomes (Jiménez et al. 1997). Like APX, GR is one of the major components in the ascorbate-glutathione cycle, by which the efficient recycling of glutathione is ensured by GR. Therefore, it plays an essential role in the protection of chloroplasts against the oxidative damage by maintaining a high reduced/oxidized glutathione (GSH/GSSG) ratio. The present study showed that the GR activity has increased with the increasing concentration of chlorpyrifos (Table 6) which could be explained in two ways: (1) the Asc-Glu cycle might be operating at a high rate in order to detoxify the ROS in Vigna, or (2) the glutathione pool has to be maintained at high levels so that it does not become a limiting factor for the synthesis of phytochelatins, the small peptides involved in the sequestrations of various metal ions in the vacuoles (Cobbett 2000; Stolt et al. 2003) and in the inactivation of pesticides by conjugate formation. It has been observed that plants under environmental stimuli tend to have high activities of GR (Batish et al. 2006). Hence, a critical role is played by GR in protecting plants against oxidative stress.

The non-enzymatic cellular antioxidants, like ascorbate and glutathione, undergo alterations under oxidative stress (Foyer and Halliwell 1976; Nakano and Asada 1981). Generated oxidative stress appears to correlate with decline in the ratio of Asc and dehydroascorbate (DHA) (Qureshi 
Table 6 Variation in glutathione reductase (GR) activity $\left(\mu \mathrm{mol} \mathrm{mg}{ }^{-1}\right.$ protein $\mathrm{min}^{-1}$ ) at various growth stages of Vigna radiata L. treated with different concentrations of chlorpyrifos

\begin{tabular}{llll}
\hline $\begin{array}{l}\text { Treatments } \\
(\mathrm{mM})\end{array}$ & Day 5 & Day 10 & Day 20 \\
\hline 0 & $3.542 \pm 0.026^{\mathrm{d}}$ & $3.571 \pm 0.044^{\mathrm{c}}$ & $3.295 \pm 0.044^{\mathrm{c}}$ \\
0.3 & $3.633 \pm 0.006^{\mathrm{c}}$ & $3.671 \pm 0.025^{\mathrm{bc}}$ & $3.440 \pm 0.028^{\mathrm{b}}$ \\
& $(2.54)$ & $(2.80)$ & $(4.55)$ \\
0.6 & $3.735 \pm 0.006^{\mathrm{b}}$ & $3.766 \pm 0.012^{\mathrm{b}}$ & $3.550 \pm 0.017^{\mathrm{b}}$ \\
& $(5.36)$ & $(5.32)$ & $(7.59)$ \\
1.5 & $3.924 \pm 0.010^{\mathrm{a}}$ & $3.972 \pm 0.007^{\mathrm{a}}$ & $3.683 \pm 0.045^{\mathrm{a}}$ \\
& $(10.73)$ & $(11.20)$ & $(11.85)$ \\
LSD at $5 \%$ & 0.05 & 0.10 & 0.11 \\
\hline
\end{tabular}

Values in parentheses indicate percentage of variation with reference to respective controls. Mean $\pm \mathrm{SE}(n=5)$. Values with different superscripts are significantly $(P<0.05)$ different from each other (Duncan's multiple range test)

Fig. 1 Variation in non enzymatic antioxidants at various growth stages of Vigna radiata $\mathrm{L}$. treated with different concentration of chlorpyrifos.

a Total ascorbate content $\left(\mathrm{mmol} \mathrm{g}^{-1} \mathrm{fw}\right)$ and $\mathbf{b}$ total glutathione content (nmol g $\left.\mathrm{g}^{-1} \mathrm{fw}\right)$. Value represents mean $\pm \mathrm{SE}(n=5)$. Values with different superscripts are significantly $(P<0.05)$ different from each other (Duncan's multiple range test)
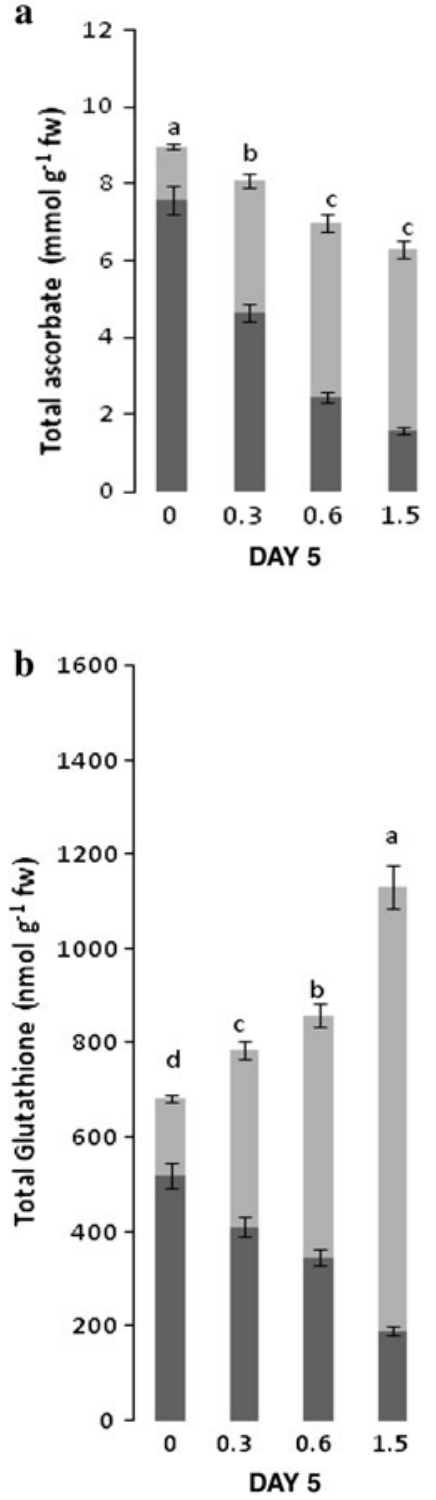

et al. 2007). In the present investigation as compared to control, a dose dependent reduction in Asc and Asc + DHA by 75.47 and $8.59 \%$, respectively, at Day 10 was observed under the highest concentration $(1.5 \mathrm{mM})$ used (Fig. 1a), but DHA content increased, resulting in a reduction in the overall ascorbate pool, which indicates a change in redox balance in the antioxidant system in response to insecticide. Similar results were reported (Qureshi et al. 2007) under heavy metal stress. Glutathione, which acts as an antioxidant, is widely believed to protect the cell against oxidative stress by maintaining cellular redox potentials. It may react directly with ROS, protect protein thiol groups form mixed disulfides with proteins, or it be involved in enzymatic detoxification of $\mathrm{H}_{2} \mathrm{O}_{2}$ (Kok De and Stulen 1993). In the present study, a dose dependent decrease was observed in GSH content by $69.78 \%$ where
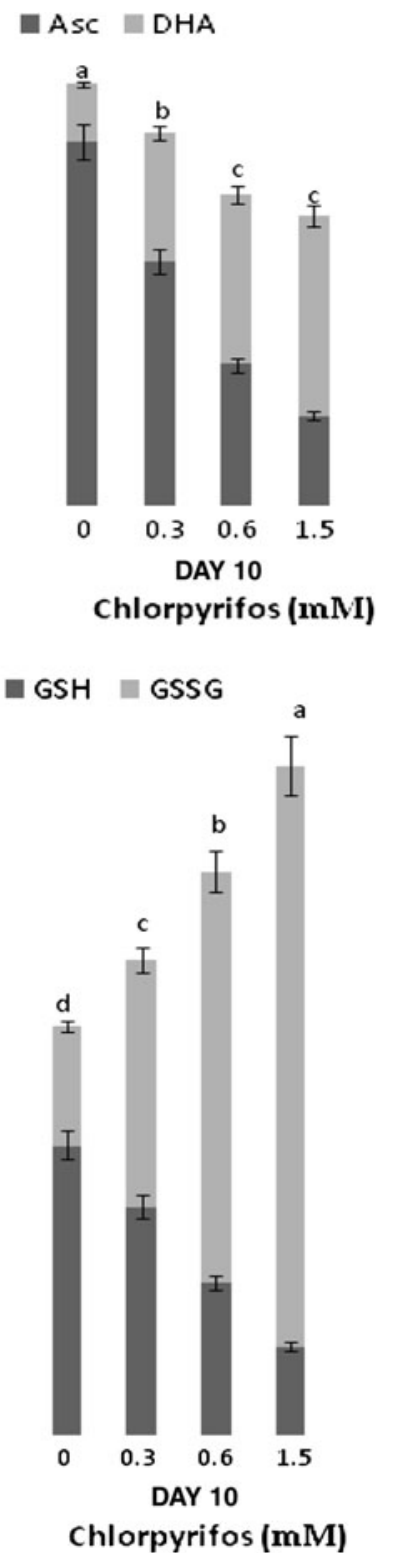
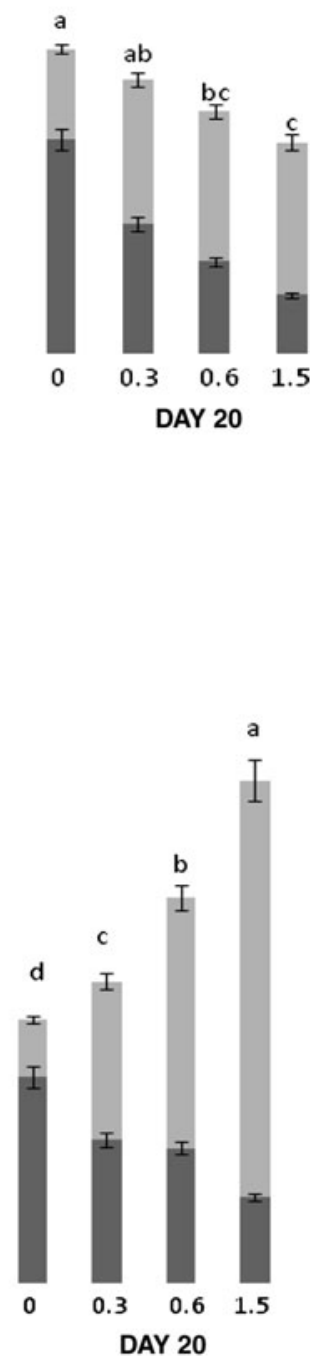
as an increase in GSSG and GSH + GSSG by 387.54 and $63.75 \%$ at Day 10 under $1.5 \mathrm{mM}$ insecticidal treatment over their respective controls (Fig. 1b). The enhanced levels of GSSG in V. Radiata due to chlorpyrifos toxicity suggest its participation in the detoxification of oxygen species and free radicals, directly (non-enzymatic) as well as through certain enzymes. It is assumed that GSH (Wingate et al. 1988) or GSSG (Winglse and Karpinski 1996) or a change between GSH and GSSG (Foyer et al. 1997) may function as signal for activating stress-responsive gene expression in stress situations.

\section{Conclusion}

The present work encompasses the responses of Vigna radiata L. against chlorpyrifos, also explicated the providence of pesticide metabolizing anti-oxidative enzyme system. Activation of metabolic processes in plant cells in response to chemical stress is manifested in (a) accumulations of proline, and (b) increase in various enzymatic and non-enzymatic antioxidants in various plant parts, thus suggesting that efficiency of Asc-Glu cycle rises in order to detoxify the ROS in the cells. Furthermore, it revealed the circuitous evidence of chlorpyrifos degradation by the increased activity status of oxido-reductase enzymes. These biochemical results can be interpreted as internal tolerance mechanisms and may allow us to develop strategies for reducing the risks of the insecticide contamination in the crop production. Enzyme expression to the gene level and degradation studies by detecting intermediary degradation compounds are the issues for future studies.

Acknowledgments First author is highly thankful to University Grants Commission (UGC), Government of India for providing fellowship during this study.

\section{References}

Aditya CN, Banerjee H, Kole RK (1997) An appraisal of pesticide use in Indian agriculture with special reference to their consumption in West Bengal. Sci Cult 63:223-228

Aebi H (1984) Catalase in vitro. Method Enzymol 105:121-126

Anderson ME (1985) Determination of glutathione and glutathione disulfide in biological samples. Methods Enzymol 113:555-570

Asada K (2006) Production and scavenging of reactive oxygen species in chloroplast and their functions. Plant Physiol 141: 391-396

Ashraf M, Foolad MR (2007) Roles of glycine betaine and proline in improving plant abiotic stress resistance. Environ Exp Bot 59:206-216

Bashir F, Siddiqi TO, Mahmooduzzafar, Iqbal M (2007a) Effect of different concentrations of mancozeb on the morphology and anatomy of Lens culinaris L. Indian J Environ Sci 11:71-74

Bashir F, Siddiqi TO, Mahmooduzzafar, Iqbal M (2007b) The anti oxidative response system in Glycine max (L.) Merr. Exposed to deltamethrin, a synthetic pyrethroid insecticide. Environ Pollut 147:94-100

Bates LS, Waldren RP, Teare ID (1973) Rapid determination of free proline for water stress studies. Plant Soil 39:205-207

Batish DR, Singh Hp, Setia N, Kaur S, Kohli K (2006) 2-Benzoxazolinone (BOA) induced oxidative stress, lipid peroxidation and changes in some antioxidant enzyme activities in mung bean (Phaseolus aureus). Plant Physiol Biochem 44:819-827

Bowler C, Anmontagu M, Inze D (1992) Superoxide dismutase and stress tolerance: annual review plant physiology. Plant Mol Biol 43:83-116

Bradford MM (1976) A rapid and sensitive method for the quantization of microgram quantities of protein utilizing the principle of protein dye binding. Anal Biochem 72:248-259

Cakmak I (2000) Possible roles of zinc in protecting plant cells from damage by reactive oxygen species. New Phytol 146:185-205

Cakmak I, Horst WJ (1991) Effect of aluminium on lipid peroxidation, superoxide dismutase catalase and peroxidase activities in root tips of soybean (Glycine max L.). Physiol Plant 83:463-468

Cobbett CS (2000) Phytochelatins and their roles in heavy metal detoxification. Plant Physiol 123:825-832

Dhindsa RS, Plumb-Dhindsa P, Thorpe TA (1981) Leaf senescence correlated with increased level of membrane permeability, lipid peroxidation and decreased level of SOD and CAT. J Exp Bot 32:93-101

Florence TM, Stauber JL (1986) Toxicity of copper complexes to the marine diatom Nitzschia closterium. Aquat Toxicol 8:11-26

Foyer CH, Halliwell B (1976) The presence of glutathione and glutathione reductase in chloroplasts: proposed role in ascorbic acid metabolism. Planta 133:21-25

Foyer CH, Lopez Delgado H, Dat JF, Scott IM (1997) Hydrogen peroxide- and glutathione-associated mechanisms of acclimatory stress tolerance and signaling. Physiol Planta 100:241-254

Gopi R, Jaleel CA, Sairam R, Lakshmanan GMA, Gomithinayagam M, Pannerselvem R (2007) Differentialn effects of hexaconazole and paclobutrazol on biomass, electrolyte leakage, lipid peroxidation and antioxidant potential of Daucus carota L. Colloids Surf B Biointerfaces 60:180-186

Haddad R, Morris K, Buchanan-Wollaston V (2009) Molecular characterization of free radicals decomposing genes on plant developmental stages. In: Proceedings of world academy of science, engineering and technology, vol 37

Halliwell B, Gutteridge JMC (1985) Free radicals in biology and medicine. Clarendon Press, Oxford

Hazarika A, Sarkar SN, Hajare S, Kataria M, Malik JK (2003) Influence of malathion pretreatment on the toxicity of anilofos in male rats: a biochemical interaction study. Toxicology 185:1-8

Howard PH (ed) (1991) Handbook of environmental fate and exposure data for organic chemicals. In: Pesticides, vol III. Lewis Publishers, Chalsea, MI

Jaleel CA, Gopi R, Alagu Lal Shmanan GM, Panneerselvam R (2006) TDM induced changes in the antioxidant metabolism and ajmalicine production in Catharanthus roseus L. G. Don. Plant Sci 7:271-276

Jaleel CA, Jayakumar K, Xing ZC, Azooz MM (2009) Antioxidant potentials protect Vigna radiata (L.) Wilczek plants from soil cobalt stress and improve growth and pigment composition. Plant Omics J 2(3):120-126

Jan S, Parween T, Siddiqi TO, Mahmooduzzafar (2012a) Antioxidant modulation in response to gamma induced oxidative stress in developing seedlings of Psoralea corylifolia L. J Environ Radioact 113:142-149

Jan S, Parween T, Siddiqi TO, Mahmooduzzafar (2012b) Effect of gamma radiation on morphological, biochemical and physiological aspects of plants and plant products. Environ Rev 20:7-39 
Jiang L, Yang H (2009) Prometryne-induced oxidative stress and impact on antioxidant enzymes in wheat. Ecotoxicol Environ Safety 72:1687-1693

Jianga L, Maa L, Suia Y, Hna SQ, Wua ZY, Fenga YX, Yanga H (2010) Effect of manure compost on the herbicide prometryne bioavailability to wheat plants. J Hazard Mater 184:337-344

Jiménez A, Hernández JA, del Rio LA, Sevilla F (1997) Evidence for the presence of the ascorbate-glutathione cycle in mitochondria and peroxisomes of pea leaves. Plant Physiol 114:275-284

Khan SM, Kour G (2007) Sub acute oral toxicity of chlorpyriphos and protective effect of green tea extract. Pest Biochem Physiol $89: 118-123$

Khan H, Zeb A, Ali Z, Shah SM (2009) Impact of five insecticides on chickpea (Cicer arietinum L.) nodulation, yield and nitrogen fixing rhizospheric bacteria. Soil Environ 28:56-59

Kok De L, Stulen I (1993) Role of glutathione in plants under oxidative stress. In: De Kok LJ, Stuten I, Rennenberg H, Brunold C, Rauser WE (eds) Sulfur nutrition and assimilation in higher plants: regulatory agricultural and environmental aspects. SPB Acedamic Publishing, The Hague, pp 125-138

Kovacik J, Klejdus B, Hedbavny J, Backor M (2009) Salicylic acid alleviates $\mathrm{NaCl}$-induced changes in the metabolism of Matricaria chamomilla plants. Ecotoxicology 18:44-554

Kumar NG, Nirmala P, Jayappa AH (2010) Effect of various methods of application of insecticides on the incidence of serpentine leaf miner, Liriomyza trifolii (burgess) and other pests in soybean. Karnataka J Agric Sci 23:130-132

Law MY, Charles SA, Halliwell B (1983) Glutathione and ascorbic acid in spinach (Spinacia oleracea) chloroplast. Biochem J 210: 99-903

MacRae EA, Ferguson IB (1985) Changes in catalase activity and hydrogen peroxide concentration in plants in response to low temperature. Physiol Plant 65:51-56

Mafakheri A, Siosemardeh A, Bahramnejad B, Struik PC, Sohrabi Y (2011) Effect of drought stress and subsequent recovery on protein, carbohydrate contents, catalase and peroxidase activities in three chickpea (Cicer arietinum) cultivars. AJCS 5(10):12551260

Mishra V, Srivastava G, Prasad SM, Abraham G (2008) Growth, photosynthetic pigment and photosynthetic activity during seedling stage of cowpea (Vigna unguiculata L.) in response to UV-B and dimethoate. Pestic Biochem Physiol 92:30-37

Mittler R (2002) Oxidative stress, antioxidants and stress tolerance. Trend Plant Sci 7:05-410

Morimura T, Ohya T, Ikawa T (1996) Presence of ascorbateperoxidizing enzymes in roots of Brassica campestris L. cv Komatsuna. Plant Sci 117:55-63

Nagesh BR, Devaraj VR (2008) High temperature and salt stress response in French bean (Phaseolus vulgaris). Aus J Crop Sci 2:40-48

Nakano Y, Asada K (1981) Hydrogen peroxide is scavenged by ascorbate specific peroxidase in spinach chloroplasts. Plant Cell Physiol 22:867-880

Panduranga MG, Mahadeva PG, Sudarshana MS (2005) Toxicity of different imbibitions periods of dimethoate on germination, chlorophyll a/b, and dry matter of Glycine max (L) Merrill. Cv. 548 KHSB-2, during early seedlings growth. J Physiol Res 18:199-201

Parween T, Jan S, Mahmooduzzafar, Fatma T (2011) Alteration in nitrogen metabolism and plant growth during different developmental stages of green gram (Vigna radiata L.) in response to chlorpyrifos. Acta physiol plant 33:2321-2328

Peixoto F, Alves-Fernandes D, Santos D, Fontainhas-Fernandes A (2006) Toxicological effects of oxyfluorfen on oxidative stress enzymes in tilapia Oreochromis niloticus. Pesticide Biochem Physiol 85:91-96

Pinto E, Sigaud-Kutner TCS, Leitao MAS, Okamoto OK, Morse D, Colepicolo P (2003) Heavy metal-induced oxidative stress in algae. J Phycol 39:008-1018

Prasad SM, Kumar D, Zeeshan M (2005) Growth, Photosynthesis, active oxygen species and antioxidants responses of paddy field cyano bacterium Plectonema boryanum to endosulfan stress. J Geb Appl Microbiol 51:115-123

Qureshi MI, Abdin MZ, Qadir S, Iqbal M (2007) Lead-induced oxidative stress and metabolic alterations in Cassia angustifolia Vahl. Biol Plant 51:121-128

Rao MV (1992) Cellular detoxifying mechanisms determine age dependent injury in tropical plants exposed 410 to SO2. J Plant Physiol 140:733-740

Rastgool L, Alemzadeh A (2011) Biochemical responses of Gouan (Aeluropus littoralis) to heavy metals stress. Aus J Crop Sci 5(4):375-383

Rusyniak DE, Nanagas KA (2004) Organophosphate poisoning. Semen Neurol 24:197-204

Saraf M, Sood N (2002) Influence of monocrotophos on growth, oxygen uptake and exopolysaccharide production of rhizobium NCIM 2271 on chickpea. J Indian Bot Soc 82:157-164

Song NH, Yin X, Chen GF, Yang H (2007) Biological responses of wheat (Triticum aestivum) plants to the herbicide chlorotoluron in soils. Chemosphere 69:1779-1787

Stevens M, Reined RF, Combs NE, Helliwell S, Jianhua Mo (2008) Influence of imidacloprid seed treatments on rice germination and early seedling growth. Pest Manag Sci 64:215-222

Stolt JP, Sneller FEC, Bryngelsson T, Lundborg T, Schat H (2003) Phytochelatin and cadmium accumulation in wheat. Environ Exp Bot 49:21-28

Venkateswara Rao J, Parvati K, Kavitha P, Jakka NM, Pallela R (2005) Effect of chlorpyrifos and monocrotophos on loco motor behavior and acetyl cholinesterase activity of subterranean termites, Odontotermes obesus. Pest Manage Sci 61:417-421

Wang L, Jiang X, Yan D, Wu J, Bian Y, Wang F (2007) Behaviour and fate of chlorpyrifos introduced into soil crop systems by irrigation. Chemosphere 66:391-396

Wingate VPM, Lawton MA, Lamb CJ (1988) Glutathione causes a massive and selective induction of plant defense genes. Plant Physiol 87:06-210

Winglse G, Karpinski S (1996) Differential redox regulation by glutathione and glutathione reductase and $\mathrm{Cu}-\mathrm{Zn}$ SOD gene expression in Pinus sylvestris L. needles. Planta 198:151-157

Wu J, Laird DA (2003) Abiotic transformation of chlorpyrifos oxon in chlorinated water. Environ Toxicol Chem 22:261-264

Wu XY, Von Tiedemann A (2002) Impact of fungicides on active oxygen species and antioxidant enzymes in spring barley (Hordeum vulgare L.) exposed to ozone. Environ Pollut 116:37-47

Wu GL, Cui EJ, Tao EL, Yang EH (2010) Fluroxypyr triggers oxidative damage by producing superoxide and hydrogen peroxide in rice (Oryza sativa). Ecotoxicology 19:24-132 